\title{
Suyya's Flood: Numerical Models of Kashmir's Medieval Megaflood and Ancient Lake Kerewa Drainage Events
}

\author{
Muntaha Urooj ${ }^{1}$, Roger Bilham ${ }^{2 \star}$, Bikram S. Bali ${ }^{3}$ and S. Imran Ahmed ${ }^{1}$ \\ ${ }^{1}$ Department of Civil Engineering, NED University of Engineering and Technology, Karachi, Pakistan, ${ }^{2}$ CIRES and Geol Sci, \\ University of Colorado, Boulder, CO, United States, ${ }^{3}$ Deparment of Earth Sciences, University of Kashmir, Srinagar, India
}

In the mid-ninth century, an earthquake triggered a landslide that blocked the narrow gorge of the Jhelum River where it exits the Kashmir Valley. The landslide impounded a lake that extended $\approx 100 \mathrm{~km}$ along the floor of the valley, implying an impounded volume of $\leq 21 \mathrm{~km}^{3}$, flooding the capital, Srinagar, and much agricultural land. An engineered breach of the landslide was contrived by a Medieval engineer resulting in the catastrophic release of flood waters. Using reasonable assumptions we calculate the probable minimum drainage time of this Medieval flood ( $<4$ days) and maximum downstream surge velocities $(\approx 12 \mathrm{~m} / \mathrm{s})$. These would have been sufficient to transport boulders in the bed of the Jhelum with dimensions of $\approx 6 \mathrm{~m}$, consistent with those currently present in some reaches of the river. Given the morphology of the Jhelum

\section{OPEN ACCESS}

Edited by: Natasha Dowey Sheffield Hallam University, United Kingdom

Reviewed by: Robert Wasson James Cook University, Australia Paul Carling,

University of Southampton, United Kingdom Simon Cook University of Dundee, United Kingdom

*Correspondence: Roger Bilham bilham@colorado.edu

Received: 02 February 2021 Accepted: 03 September 2021 Published: 04 October 2021

Citation: Urooj M, Bilham R, Bali BS and Ahmed SI (2021) Suyya's Flood: Numerical Models of Kashmir's Medieval Megaflood and Ancient Lake Kerewa Drainage Events. Earth Sci. Syst. and Soc. 1:10040. doi: 10.3389/esss.2021.10040 gorge we consider that landslide outburst floods may have been common in Kashmir's history. Ancient shorelines indicate that paleo-lake volumes in the Kashmir Valley may have exceeded $400 \mathrm{~km}^{3}$ which, were they released in catastrophic floods, would have been associated with potential downstream outburst velocities $>32 \mathrm{~m} / \mathrm{s}$, able to transport boulders with dimensions $\approx 40 \mathrm{~m}$, far in excess of any found in the course of the Jhelum or in the Punjab plains. Their absence suggests that Kashmir's ancient lakes were not lowered by outburst mechanisms much exceeding those associated with Suyya's flood. Present-day floods have been many tens of meters shallower than those impounded by landslides in the Jhelum in the past several thousands of years. A challenge for future study will be to date Kashmir's ancient shorelines to learn how often landslides and major impoundment events may have occurred in the valley.

Keywords: landslide induced floods, Kashmir, mega-boulder transport, Jhelum erosion, Holocene mega floods, Lake Kerewa

\section{INTRODUCTION}

The thick fluvial Kerewa sediments that cover more than $50 \%$ of the floor of the Kashmir Valley require an extensive lake to have flooded part or all of the valley throughout much of the past 4 million years - Lake Kerewa. The sediments consist of fine muds, interrupted by coarse sands and conglomerates indicating periods of drainage, erosion and uplift associated with disturbances associated with progressive thrust faulting beneath the Pir Panjal range (Burbank and Johnson, 1982,1983; Agarwal et al., 1989; Bhatt, 1989; Basavaiah et al., 2010), which has raised the southernmost sediments of the Lower Kerewa more than $3 \mathrm{~km}$ above their 


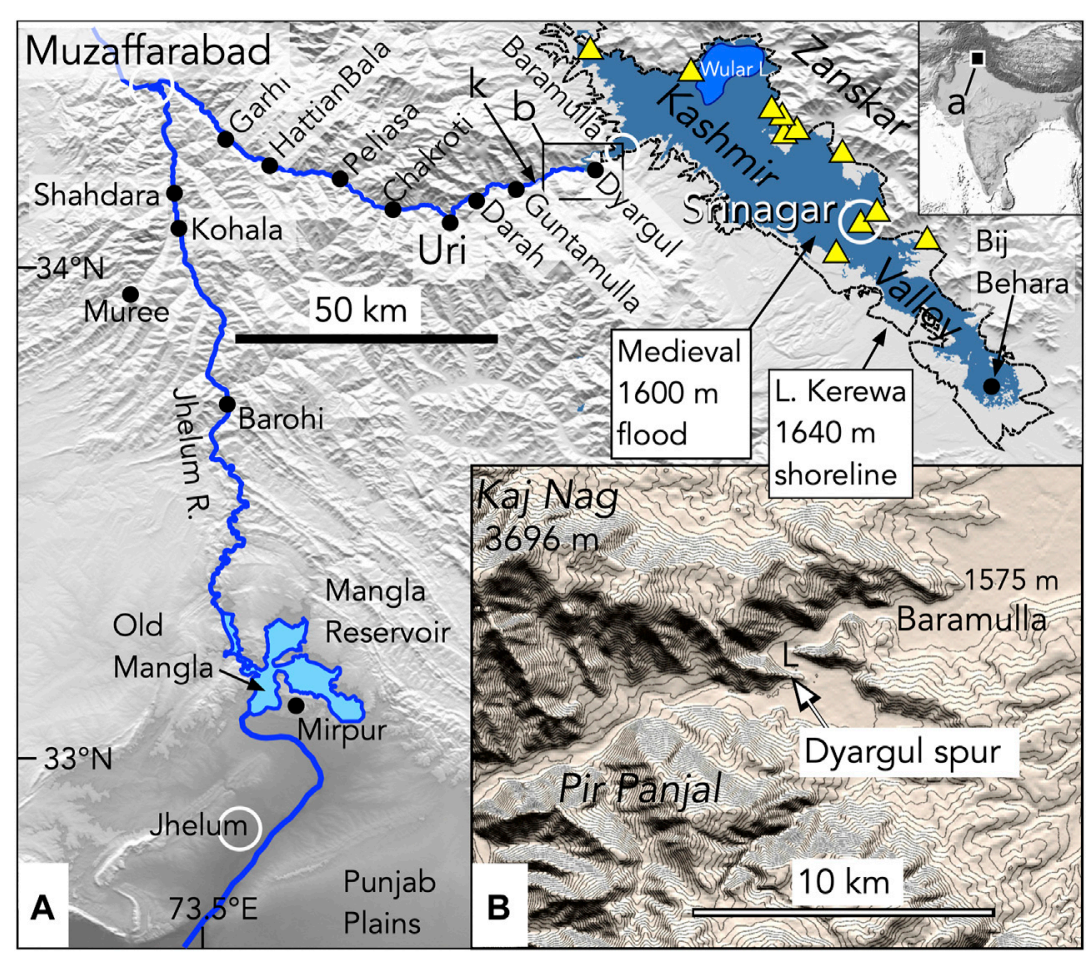

FIGURE 1 | (A) An engineered breach of an earthquake-induced landslide in the Jhelum gorge below Baramulla drained an inferred $\leq 21 \mathrm{~km}^{3}$ transient lake in the Kashmir Valley whose surge to the Punjab plains we quantify analytically at the named locations. Point "k" indicates the knickpoint transition from shallow to steep channel gradients caused by headward erosion of the Jhelum. Wular Lake is the largest present-day lake in the Valley (depth $\leq 14 \mathrm{~m}$ ). The Medieval flood level (shaded blue) indicates the inferred lake whose catastrophic drainage we model in the current article. Yellow triangles indicate the locations of sequences of ancient lake shorelines mapped by DeTerra and Paterson (1939) that document a dominant 1,640 \pm 10 m shoreline (dashed, see Figure 2). White circles indicate cities; black dots villages (B) A inferred $25 \mathrm{~m}$ high landslide at Dyargul (near point L) flooded the Kashmir Valley up to the village of Bij Behara.

counterparts in the present valley floor. Acceleration of this uplift occurred towards the present time, and in the past $200 \mathrm{ka}$ it has averaged $>3.5 \mathrm{~mm} / \mathrm{yr}$ (Burbank and Johnson, 1983).

Substantial drainage of ancient Lake Kerewa occurred approximately 85 ka BP (Agrawal et al., 1989) through a single outlet from the valley, the Jhelum gorge. The base level of this gorge currently has a gentle gradient $(0.07 \%)$ for its $13 \mathrm{~km}$ channel east of Baramulla, and acts as a broad weir regulating the maximum depth of flooding in the Kashmir Valley. Isolated, present-day vestiges of Lake Kerewa (Wular, Anchar, Dal and Manasbal Lakes, all with depths less than $14 \mathrm{~m}$ ) are pinned to the NE edge of the valley as a result of uplift of the Pir Panjal range. With sedimentation rates of 0.15-0.44 mm/a (Shah et al., 2019; Lone et al., 2020) these surviving lakes would fill with sediment were it not for the persistent rise of the Jhelum's outlet above the NE side of the valley, which increments at the time of great thrust earthquakes beneath the Pir Panjal. Depending on the throw of these earthquakes each new event increases lake capacity, and the potential maximum depth of flooding.

In contrast to these tectonic events, transient flooding of the Kashmir Valley can occur as a result of landslides that block the path of the Jhelum downstream from Baramulla (Figure 1). These floods develop rapidly, and potentially to great depth, but are impermanent because once their impounded waters overtop the debris obstructing the river bed, hydraulic incision occurs, typically leading to rapid drainage and a catastrophic surge downstream. One such natural dam was triggered by an earthquake in the ninth-century CE.

The purpose of this article is to quantify the hazard characteristics of this ninth-century landslide following its engineered removal by Medieval manpower and hydraulic incision. The volume of water released by breach of the debris dam $\left(\leq 21 \mathrm{~km}^{3}\right)$ is calculated to have exceeded that of the two largest Indus floods in the 19th century (Delaney and Evans, 2011). It is also possible that much larger floods have occurred in Kashmir's recent history. As related by Kalhana (Stein, 1898) and Hassan in 1896, the mythical origins of Kashmir involve the drainage of a large lake that once occupied the valley. Hassan (1896, Tarikh-i-Hassan, 1: 55-56) invokes archaeological evidence for the myth in the form of stone boat anchors occasionally found far above present lake levels. It is improbable that these legends recall high-stands of Pleistocene Lake Kerewa (>200 ka BP) (Agarwal et al., 1989), but they may represent a memory of the formation and drainage of one or more transient landslide-impounded, lake-levels subsequent to the Neolithic $(\approx 5 \mathrm{ka} \mathrm{BP})$ occupation of the valley (Spate, 2019). 
We first summarize what is known of the ninth-century landslide and flood in the Kashmir valley, and the events associated with its engineered breach. We then proceed, using simple hydraulic modeling, to calculate the maximum downstream effects of the catastrophic surge in the Jhelum gorge. To evaluate whether our maximum calculated surge velocities are reasonable we use remote imagery to quantify boulder dimensions in the present day river bed along its channel from Kashmir to the Punjab. We find that Suyya's flood (draining a $25 \mathrm{~m}$ deep lake) would have been insufficient to mobilize the largest boulders in the Jhelum above Muzaffarabad, but that a significant fraction could have been mobilized by an inferred much larger flood surge associated with the catastrophic drainage of a 70 m-deep Lake Kerewa, corresponding to the $\approx 1,640 \mathrm{~m}$ dominant shoreline level documented by De Terra and Paterson (1939).

Finally, we compare the parameters of Suyya's flood with recent major floods in Pakistan, and inferred potential ancient Lake Kerewa floods, where lake volumes of $\approx 400 \mathrm{~km}^{3}$ are implied by shoreline levels $\leq 273 \mathrm{~m}$ above the valley floor. Were these high Lake Kerewa impoundment levels drained by catastrophic breaches we calculate they would have been able to transport boulders with dimensions up to $25 \mathrm{~m}$ to points where the Jhelum currently debouches into the plains of the Punjab, or to former debouchment levels on the eastern Potwar plateau. Their absence suggests that outburst floods much larger than the one we study here may not have occurred.

\section{HISTORY OF SUYYA'S FLOOD}

A description of the formation of a Medieval landslide dam is mentioned in two historical Kashmiri accounts: Kalhana's epic Sanskrit poem Rajatarangini (Stein 1898, 5,72-109) written c. 1,149 , roughly two centuries after the events surrounding the flood, and Tarikh-i-Hassan (Hassan, 1896), which was compiled from multiple sources including Kalhana's account, but which, though briefer, provides a named location for the river blockage and adds that the landslide was induced by an earthquake that occurred during the night. Both accounts imply or state that the landslide occurred near the village of Khadanyar, and impounded floodwaters as far as the town of Bij Behara. Verbatim translations of these accounts are reproduced in lyengar et al. (1999) and Bilham and Bali (2013). The earliest of the 16 floods mentioned in Tarikh-i-Hassan, which refers to Kashmir's mythical origins (c. 5 ka $\mathrm{BP})$, mentions a similar earthquake-triggered landslide that also caused flooding up to Bij Behara, raising possible concerns of conflation in the two entries by Hassan (1896). The drainage of this early mythical flood, devoid of detail, appears in some interpretations of the Vedic Puranas attributed to Kashyap Reshi.

According to the stanzas of the Rajatarangini, Avantivarnan, who ruled Kashmir between 855 and $883 \mathrm{CE}$, learned that one of his citizens, Suyya, who is described in mythical terms as having been found abandoned on the roadside as a baby, but whose wisdom as an adult led to him being recognized as an educator and advisor (Stein 1898, 5:78), and who has subsequently been described as a Medieval engineer, claimed to know of an innovative way to remove the mass of the dam, had he the means at his disposal. Upon enquiry, Suyya's solution was to ask for money.

Avantivarnan was intrigued, but after providing the requested funding was surprised when Suyya proceeded to throw handfuls of coins from his treasury into the deep waters of the impounded lake. He did so at two locations, a potful at Nandaka whose historical location southeast of Srinagar is uncertain, and handfuls at Yaksadara, $\approx 7 \mathrm{~km}$ downstream from Baramulla near Khadanyar (Figure 1). Most of the king's court considered these actions to be those of a madman, but the king remained unperturbed. Suyya had surmised that the promise of retrieving the coins would be sufficient to motivate onlooking villagers to work with him to clear the dam. The mitigation measures described by Kalhana were interpreted by Bilham and Bali (2013) as follows: initial attempts to excavate a spillway across the dam were ineffective in draining the lake, requiring the construction of a temporary coffer dam to restrain the upstream flood waters while a deeper path though the landslide was excavated. The new channel was partly lined to prevent collapse, but designed to be sufficiently deep to promote self-scouring and headward erosion. Upon breach of the coffer dam, hydraulic incision and erosion enlarged a path through the dam that ultimately drained the lake. It is unknown whether the river had overtopped the dam prior to its breach, but it must have been close to doing so for it to have been deemed necessary to construct a temporary dam.

No independent historical or paleoseismic data are currently available that might improve constraints on the date of the earthquake that triggered the landslide. It is possible, moreover, that the earthquake may have been quite local and of inconsiderable magnitude. In popular accounts the date of the earthquake that triggered the slide is frequently cited as the last year of Avantivarnan's reign (883 CE). This is almost certainly wrong because tens of $\mathrm{km}$ of canals and earthworks were completed, followed by agricultural irrigation projects that resulted in a sixfold decrease in the cost of grain, requiring the flood to have been drained many years before Avantivarnan's death. If the flood preceded Avantivarnan's temple construction achievements, it may have occurred near the start of his reign. This appears likely because no mention is made in the Rajatarangini of submergence of his then newly constructed temples.

\section{LANDSLIDE LOCATION, CREST ELEVATION AND VOLUMES OF ANCIENT LAKES}

From places mentioned in the historical accounts we next identify the location of the Medieval landslide, its crest elevation and the resulting depth of flooding in the Kashmir Valley. From flooding depths in the Medieval account, and from former shorelines we calculate the volume of ancient lakes in the Kashmir Valley.

The Rajatarangini and Tarikh-i-Hassan narratives both indicate that floodwaters backed up the valley to a location approximately $100 \mathrm{~km}$ SE from Baramulla (Figure 1). The Rajantarangini mentions an "unfathomable depth" flood at Nandaka, which Stein speculates as being sited between Bij Behara $\left(33.81^{\circ} \mathrm{N}, 75^{\circ} 09^{\prime} \mathrm{E}\right)$ and Anantnag $\left(33.74^{\circ} \mathrm{N}, 75.14^{\circ} \mathrm{E}\right)$ 

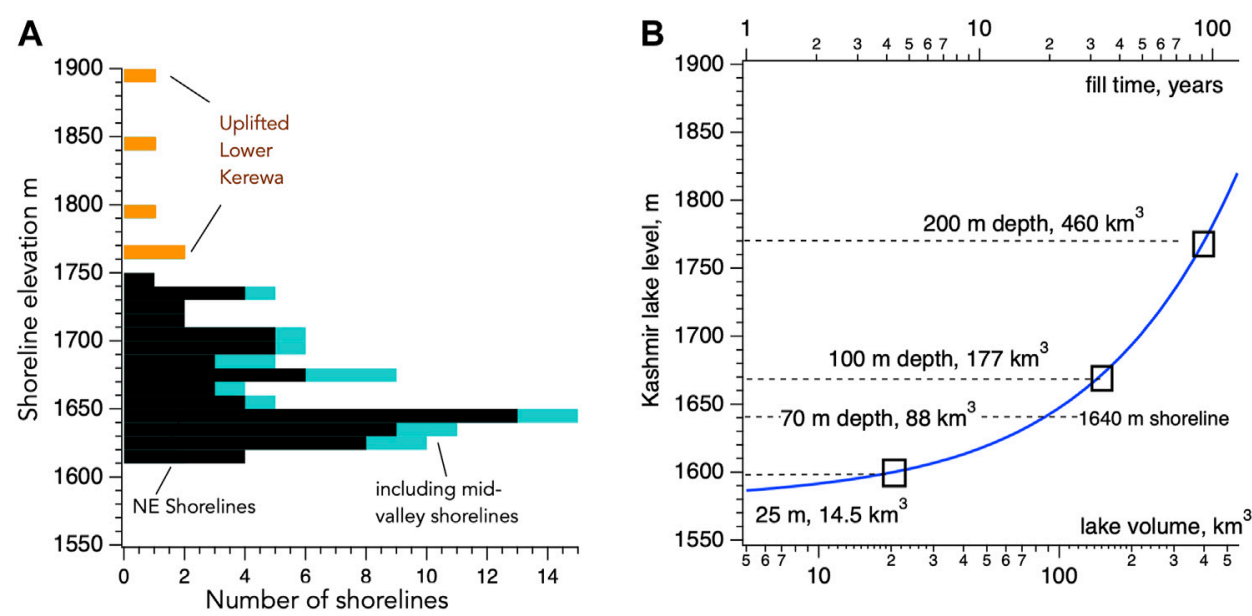

FIGURE 2 | (A) Histogram of 88 ancient Lake Kerewa shoreline levels reported by De Terra and Paterson (1939) (see Supplementary Material 1). Although undated, those above $1750 \mathrm{~m}$ are considered tectonically uplifted Lower Kerewa shorelines (orange). Those below $1740 \mathrm{~m}$ (black) show a prominent peak near the 1,640 m contour, and many are incised into or deposited on Lower Kerewa deposits. Those in blue are shoreline elevations from near the central axis of the valley (on the western 1,640 m shoreline in Figure 1). (B) Flood elevation, fill time and impounded volume for lakes in the Kashmir Valley (blue curve). Fill-time assumes a mean annual Jhelum discharge of $237 \mathrm{~m}^{3} / \mathrm{s}$ (see text). In addition to Suyya's $25 \mathrm{~m}$ breach at Dyargul (Figure 3), we consider the failure of three landslide dams of different height at Gantamulla (Figure 1), the first impounding the same depth and similar volume as Suyya's landslide, and others impounding lakes with $100 \mathrm{~m}$ and $200 \mathrm{~m}$ depths.

near the low lying districts adjoining the ancient Naindee Canal (Montgomerie, 1859). Hassan (1896) specifically mentions Bij Behara. The low-lying parts of Bij Behara lie at an elevation of $1952.5 \mathrm{~m}$ and the high ground lies at $1,600 \mathrm{~m}$. The river level at the outlet of the Kashmir Valley is approximately $1,575 \mathrm{~m}$ and in the next $10 \mathrm{~km}$ it descends with a mean gradient of $0.67 \mathrm{~m} /$ $\mathrm{km}$. A landslide less than $5 \mathrm{~km}$ downstream from Baramulla would thus have a base height of $1,572 \mathrm{~m}$, implying a base to crest height of $20.5-28 \mathrm{~m}$. In subsequent calculations a landslide thickness of $25 \mathrm{~m}$ was adopted.

From digital terrain imagery it is possible to calculate the volume of water impounded below the highest inferred flood level of $1,600 \mathrm{~m}$ as $21 \mathrm{~km}^{3}$ (Figure 2). If floodwater onlapped the lower ground at Bij Behara the impounded volume would have been $11.5 \mathrm{~km}^{3}$. If we assume that the mean Jhelum annual discharge and standard deviation of $237 \pm 94 \mathrm{~m}^{3} / \mathrm{s}$ (observed between 1968 and 1979, Vörösmarty et al., 1998) prevailed in Medieval times, we calculate it would have required $2.6 \pm 1$ year to flood the $1,600 \mathrm{~m}$ contour. If the minimum mean annual $96 \mathrm{~m}^{3} / \mathrm{s}$ discharge measured in 1971 is used, the estimated fill time increases to 7 years.

Numerous ancient shorelines surround the edges of the Kashmir Valley (Figure 1) indicating that it has been flooded to depths in excess of $150 \mathrm{~m}$ above the $\approx 1,600 \mathrm{~m}$ level associated with the ninth century flood. De Terra and Paterson (1939) quantify 88 beach levels at more than ten locations in the northern valley (Figure 2B, and Supplementary Material 1). Five shorelines higher than $1750 \mathrm{~m}$ are considered to date from Lower Kerewa times, and appear to have been deformed and raised to their current positions by faulting beneath the northern edge of the valley. Those lower than $1740 \mathrm{~m}$ (lake depths $\leq 150 \mathrm{~m}$ ) are consistent with the $200 \mathrm{~m}$ depth range compatible with Upper Kerewa ostracods (Kramer and Holmes, 2009). However, these lower shorelines, with a peak distribution at $\approx 1,640 \mathrm{~m}$, appear to mantle, or have been eroded into Upper Kerewa deposits implying that they record lake levels that prevailed in the past $87 \mathrm{kBP}$ (Agarwal et al., 1989). We are unaware of subsequent dating of these shorelines, but if they prove to be post-Neolithic they may have been the source of the legends concerning the origins of Kashmir following the mythical drainage of a former lake discussed above.

Since most of these relict shorelines are centered NE of the axis of NE tilting in the Kashmir Valley (Burbank and Johnson, 1983) they provide reliable indicators of the true depth of flooding above the current Wular Lake level (Figure 1). Further indication that the shoreline elevations are not biased by tilting of the valley, is that those on the west shore of the $1,640 \mathrm{~m}$ Lake Kerewa shoreline, (blue in Figure 2A), show a similar height distribution to those on the NE shoreline (black). In Figure 2B we quantify impounded lake volume and the time to fill hypothetical lakes associated with the shorelines depicted in Figure 2A. If 19th century Jhelum discharge prevailed, it would take about a century to fill to the $1,170 \mathrm{~m}$ contour. The mean increment between shoreline levels observed at each of the shoreline sequence is $3-7 \mathrm{~m}$, leading De Terra and Paterson (1939) to interpret their regularity as recessional levels. We note that had a persistent erosion-resistant sill level maintained the Jhelum outlet, they could alternatively have recorded incremental uplift of this sill accompanying great earthquakes, with slip of $4-9 \mathrm{~m}$ on $\mathrm{a} \approx 40$ dipping thrust plane beneath the Pir Panjal. In this interpretation the 


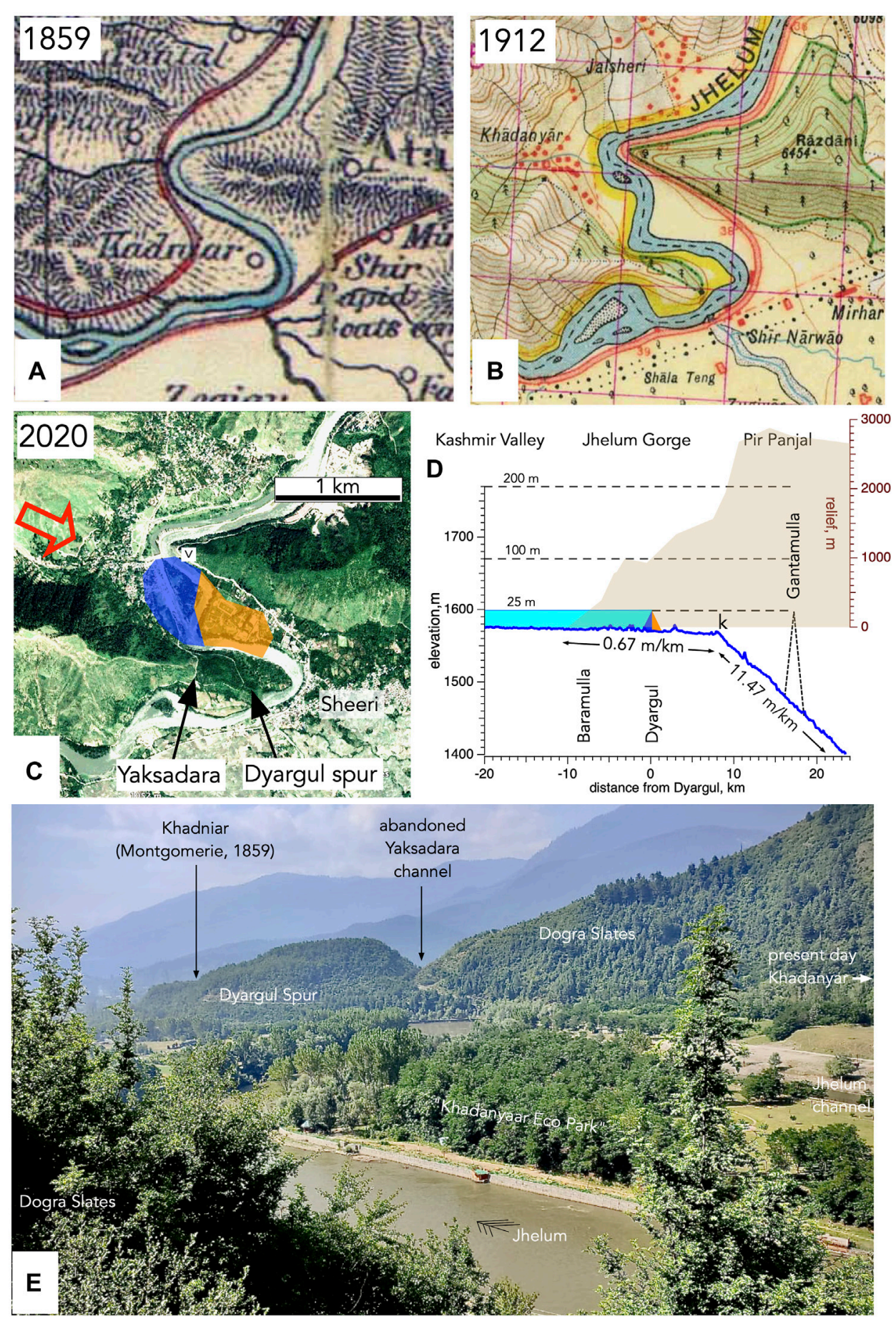

FIGURE 3 | Historical and present-day maps of the inferred location of Suyya's landslide north of the Dyargul spur (A) Montgomerie 1/4" scale (1859) (Waugh, 1859), (B) Burrard, 19131" scale (1912), and (C) lower left Google Earth (2020). Conjectural geometry for Suyya's landslide is shaded blue upstream, and orange downstream cresting at $25 \mathrm{~m}$ near the abandoned river channel of Yaksadara. Red arrow indicates possible landslide flow path. Point V indicates vantage point of photograph in (E). (D) Cross-section of the dam, river profile and PirPanjal/ KajNag relief adjoining the Jhelum Gorge (note 1/10 vertical scale right). Suyya's $25 \mathrm{~m}$ high dam is shown impounding a lake near Dyargul. Dashed lines (left scale) illustrate the location and flooding depth of three hypothetical landslide dams at Gantamulla considered in later modeling. Headward erosion of the Jhelum terminates near point " $k$ " (knickpoint at $34.17^{\circ} \mathrm{N}, 74.24^{\circ} \mathrm{E}$ in Figure 1) close to the mapped location of the Himalayan Main Central Thrust (Seeber and Gornitz, 1983). (E) 2021 photo of Yaksadara/Dyargul region viewing south from point " $v$ " in panel (C). We envisage the landslide entered from the right (west) and blocked the valley to the base of the Yaksadara channel (see Supplementary Material 3 for additional views). 
Jhelum outlet would have incremented upward for several earthquake cycles, each cycle with a duration of 300-900 years if current geodetic rates were applicable (Bilham, 2019), before drainage of the lake following an abrupt erosion event within the Jhelum gorge, such as the one we are considering in this article.

It is uncertain how long a lake-level must be maintained to develop a shoreline or incise a hillside notch in the Kashmir Valley. Moreover, from deTerra and Paterson's descriptions we are unable to distinguish between a record of multiple lakes, or a single lake with long duration. Recessional berms in the Salton Sea, California are associated with multiple lakes that filled rapidly and evaporated slowly in the past several thousand years. Their high stands persisted for many decades during which bedrock erosion occurred. Evaporation occurred slowly and is recorded by a regular suite of recessional seasonal shell and shingle deposits, which apparently erased earlier shorelines (Rockwell et al., 2018). In Kashmir, the opposite occurs - periodic monotonic filling moderated by seasonal water supplies, followed by rapid drainage and a downstream flood. Since filling would take 3-100 years depending on depth (Figure 2B), lake growth shorelines might be expected to record seasonal maxima, which would not be erased during a landslide breach event, which, as we show below, may occur in just a few days. The above considerations lead us to conclude that ancient beach levels may have formed in the Kashmir Valley during lake growth episodes.

\section{LANDSLIDE LOCATION}

The two historical accounts provide different names for the location of the ninth-century landslide. Stein (1897; 1899a,b) who travelled extensively throughout the valley comparing Kalhana's Medieval geography and place names with those mapped by Montgomerie (1859), deduced that the landslide had blocked the river north of an abandoned river channel $\left(34.187^{\circ} \mathrm{N}, 74.299^{\circ} \mathrm{E}\right) \approx 100 \mathrm{~m}$ above the present channel known as Yaksadara (Figure 3, the Demon's cleft), where Kalhana relates that coins were thrown into the flood. Hassan (1896) mentions that the landslide occurred near Khadanyar, which on maps available to him (Montgomerie, 1859; Walker, 1867) is shown at the tip of the east-facing spur $\left(34.186^{\circ} \mathrm{N}, 74.307^{\circ} \mathrm{E}\right)$, $600 \mathrm{~m}$ east of Yaksadara. Walker (1867) misprints the name at this same location as Khadriar.

This spur (Supplementary Material 3) directs the river Jhelum $1 \mathrm{~km}$ eastward toward the village of Sheeri $\left(34.184^{\circ} \mathrm{N}, 74.313^{\circ} \mathrm{E}\right)$ after which the river veers southward and then west (Figures 1, 3). Upstream from Sheeri the river meanders within a flat-bottomed valley, at its narrowest $490 \mathrm{~m}$ wide, with flanking hillslopes rising $\approx 400 \mathrm{~m}$ above the valley floor, within a $60 \mathrm{~m}$ wide channel in the dry season which broadens to $100 \mathrm{~m}$ during spring floods (Figure $\mathbf{3}$ ).

In 1892 Stein visited the location and learned the spur was locally known as Dyargul, a name derived from the root Dyar, a Kashmiri word for money or treasure, suggesting to him a thousand-year, oral tradition of the Suyya legend. Villagers, however, had retained no memory of this historical connection. The eastern tip of Dyargul spur is marked on the 1859 map as "rapids" - the lowest navigable point that boats on the Jhelum river could reach from Srinagar. The rapids correspond to the location of Shir Narwao where De Terra and Paterson (1939 p.116) conjecture that faulting in the stream bed may have been responsible for the impoundment of ancient Kashmir lakes. Of this location Verchère (1866 p. 95) also infers the existence of a fault: "The Jhelum, while in the fault is narrow but navigable; at the ravine, it turns suddenly to the south, quitting the fault and passing over a band of rock which stretches from W. to E. thus supporting a small rapid". The rapids are presently expressed weakly only during the time of low flow and are not associated with any significant change in the gradient of the river (Figure 3D).

The hillsides flanking the river downstream from Baramulla consist of Cambrian Dogra Slates, (Verchère, 1866; Wadia, 1919; Wadia, 1934). Angular boulders of slate are strewn in the east-facing valley leading above the present village of Khadanyar, the largest with dimensions exceeding $6 \mathrm{~m}$. Angular blocks of slate ( $\leq 2 \mathrm{~m}$ dimensions) surface the triangular-shaped island in the Jhelum below the village, known as the Khadanyaar (stet) Eco Park. A 2008 commemorative plaque in the park summarizes the Vedic account of the mythical drainage of the Kashmir Valley, but omits mention of the Medieval operations of Suyya.

The northern and southern entrances to the $\approx 200$ m-long Yaksadara channel were measured with a handheld GPS unit to lie at an elevation of $1,610 \pm 5 \mathrm{~m}$. At an elevation of $1,643 \pm 5 \mathrm{~m}$, the highest point of the Yaksadara channel, $\approx 68 \mathrm{~m}$ above the current level of the Jhelum, corresponds to the approximate level of the dominant shorelines in the Kashmir Valley. The channel is approximately $10 \mathrm{~m}$ wide at its base and is incised through NE dipping Dogra slates. Just below its northern entrance we mapped a coarse cemented breccia containing equidimensional unsorted angular fragments of slate (Supplementary Material 3). Although these may represent slope-wash from the nearby hillsides, the largest fragments $(\leq 40 \mathrm{~cm})$ do not resemble the tabular debris fragments typical of talus deposits in eroded Dogra slates. We conjecture that the slate breccia may be a relict of the Medieval landslide, or a former landslide.

The location would appear to be well-constrained were it not for an ambiguity in Tarikh-i-Hassan's account that speaks of boulders falling from the "mountainous ridge" of Khadanyar, suggesting the name refers to a mountain and not to a village. 20th century maps show the village of Khadanyar at $34.19^{\circ} \mathrm{N}, 74.29^{\circ} \mathrm{E}$ (Burrard, 1912) $1 \mathrm{~km} \mathrm{NW}$ of Yaksadara, the current name of the village and the river park near that location. In contrast, Google Earth imagery (2021) assigns this name to a village east of the Jhelum at $34.20^{\circ} \mathrm{N}, 74.31^{\circ} \mathrm{E}, 1 \mathrm{~km}$ SE of Sheeri, for which there is no historical precedent. We reconcile these ambiguities by assuming that the landslide originated from the $1 \mathrm{~km}$ high slopes to the west of, and above, Montgomerie's "Kadniar" and blocked the Jhelum channel to the north of the Dyargul spur (Figure $3 \mathbf{C}$ ). 
Had the course of the river been entirely blocked north of the Dyargul spur, the landslide would have measured $\approx 1 \mathrm{~km}$ alongstream, $590 \mathrm{~m}$ wide at its base between rock walls and $\approx 25 \mathrm{~m}$ high, a volume of $\approx 12.2 \times 10^{6} \mathrm{~m}^{3}$ (Figure $3 \mathrm{E}$ ). It is probable that the landslide was irregular in shape and that it blocked only part of this segment with a crest-height near, or to the east of the Yaksadara cleft. In subsequent calculations we estimate the breach time of a landslide with crest height of $20 \mathrm{~m}$ or $25 \mathrm{~m}$ and a rock-channel width of $590 \mathrm{~m}$ (Supplementary Material 2).

Several landslide-prone hillsides are evident along the path of the Jhelum downstream from the Dyargul spur (Figure 1B) that may have been responsible for ancient landslides, but whose locations are inconsistent with the descriptions of Suyya's landslide removal activities. Locations for a landslide dam upstream from Dyargul are likewise incompatible with the Rajatarangini narrative since they would have prevented flood waters from reaching Yaksadara.

\section{FLOOD CALCULATIONS}

In this section we consider the simplest of breach scenarios and its subsequent downstream flood. Our intent is to evaluate the flood hazard resulting from potentially large transient stream velocities and their associated local flood surge heights along the valley sides. The geometry and rheology of the landslide are insufficiently determined for complex scenarios to be considered. We also omit the contribution from tree and rock debris that may have been responsible for the transformation of the flood to a debris flow. Incorporated debris can increase bed shear forces, erosion and mass transport (Cui et al., 2010).

This worse-case scenario necessarily involves rapid collapse of the landslide dam, and the forging of a sufficiently wide channel to rapidly evacuate the flood in the Kashmir Valley (as implied by the Medieval account). It is related that Suyya seeded incision by constructing a narrow channel to maximize the effects of erosion. Several empirical formulae address this form of failure, known as overtopping (Froehlich, 2008; Zhong et al., 2021). We calculated the average breach width associated with erodible landslides, and the time taken to widen the channel to the average $590 \mathrm{~m}$ width of the rock channel at Dyargul using eight empirical models (supplementary Material 2). These yielded an average widening time of $27 \pm 24 \mathrm{~h}$ and $7 \pm 8 \mathrm{~h}$ for $20 \mathrm{~m}$ and $25 \mathrm{~m}$ high dams respectively. The median times to erode the full width of the $590 \mathrm{~m}$-wide channel were 14.1 and $4.9 \mathrm{~h}$ for $20 \mathrm{~m}$ and $25 \mathrm{~m}$ high dams. Assuming a linear relationship for breach widening, the median times taken to widen the breach to the current $130 \mathrm{~m}$-wide channel for $20 \mathrm{~m}$ and $25 \mathrm{~m}$ dam were 13 and $4 \mathrm{~h}$ respectively, short compared to the computed drainage time of the lake we calculate below.

We used the Hydrologic Engineering Center's River Analysis System software (HEC-RAS, Brunner, 1995; Brunner et al., 2018) to compute valley drainage time, discharge, velocity and the flood surge height as a function of location and time downstream. To determine the morphology of the lake floor and the Jhelum channel we interpolated $10 \mathrm{~m} \times 10 \mathrm{~m}$ data from $30 \mathrm{~m}$-footprint Shuttle Radar Topography Mission elevation data (Farr et al., 2007). These data accurately depict the Kashmir Valley's storage elevation vs volume curve shown in Figure 2, but provide an overly smoothed channel geometry used by the downstream flood surge model. In locations within the Jhelum gorge between Gantamulla and Muzafferabad more realistic channel geometries were incorporated to emulate the incised rectangular stream channel (Supplementary Material 3). For the now-submerged valley beneath the Mangla Reservoir we digitized the topography from pre-1960 maps of the Mirpur region.

The drawdown of the Kashmir Valley flood waters was calculated assuming a stream width of $130 \mathrm{~m}$ and an impounded water volume of $17.5 \mathrm{~km}^{3}$. The channel-width between bed-rock walls at Dyargul at the time of failure could have been up to $590 \mathrm{~m}$ (Supplementary Material 2), but the gorge between Baramulla and Dyargul would have moderated flow rates. The concave-up drawdown curve for lake level in the Kashmir Valley (Figure 4A) integrates the effects of the diminishing hydraulic head with time and the reduction in surface area of the impounded lake as the valley drains. A time step of $0.1 \mathrm{~s}$ was used for the downstream calculations, initially with a smooth channel with a Manning's coefficient of 0.045 . We adopted a Punjab outflow with an energy slope of $0.46 \%$, although numerical tests showed that model results were insensitive to our choice for this value.

The Jhelum channel, for much of its course below Gantamulla, flows within a 30-50 m wide trapezoidal-shaped, steep-sided, 5-30 m deep channel, devoid of vegetation, flanked by two or more terraces now covered by villages and agricultural fields. In Medieval times terraces and hillslopes above the main channel were presumably mostly forested. Accordingly we ran a second suite of numerical models in which the central $50 \mathrm{~m}$ wide segment of the channel was assigned a low Manning's coefficient, but everything outside this $50 \mathrm{~m}$-width was assigned a Manning's coefficient of 0.16 , appropriate for forest cover. In view of the absence of a detailed digital elevation model sufficient to precisely define channel geometry, we chose to ignore the added complications of including the detailed geometry of flanking terraces (Supplementary Material 3). As a result, our "forested" models represent an approximation to the actual behaviour of the flood, however, we note that crosssectional area of the rectangular channel, where we have included it, represents only $\approx 10 \%$ of the calculated crosssectional area of the flood surge, and so its precise definition does not unduly influence our results.

The calculated surge time history as the flood made its way down the Jhelum valley towards the Punjab plains is plotted for selected locations (Figure 4). The dominant characteristic at any specific location is that of a gradually increasing surge of high velocity flood water whose peak flood depth decreases from $\approx 29$ m below the dam to $<15 \mathrm{~m}$ near Mangla, with the time of the peak moving slowly down stream, at a phase velocity initially of $6.4 \mathrm{~km} / \mathrm{h}$ speeding up to $17.3 \mathrm{~km} / \mathrm{h}$ near the Punjab (Figure 4B). Our calculations indicate that although the flow 


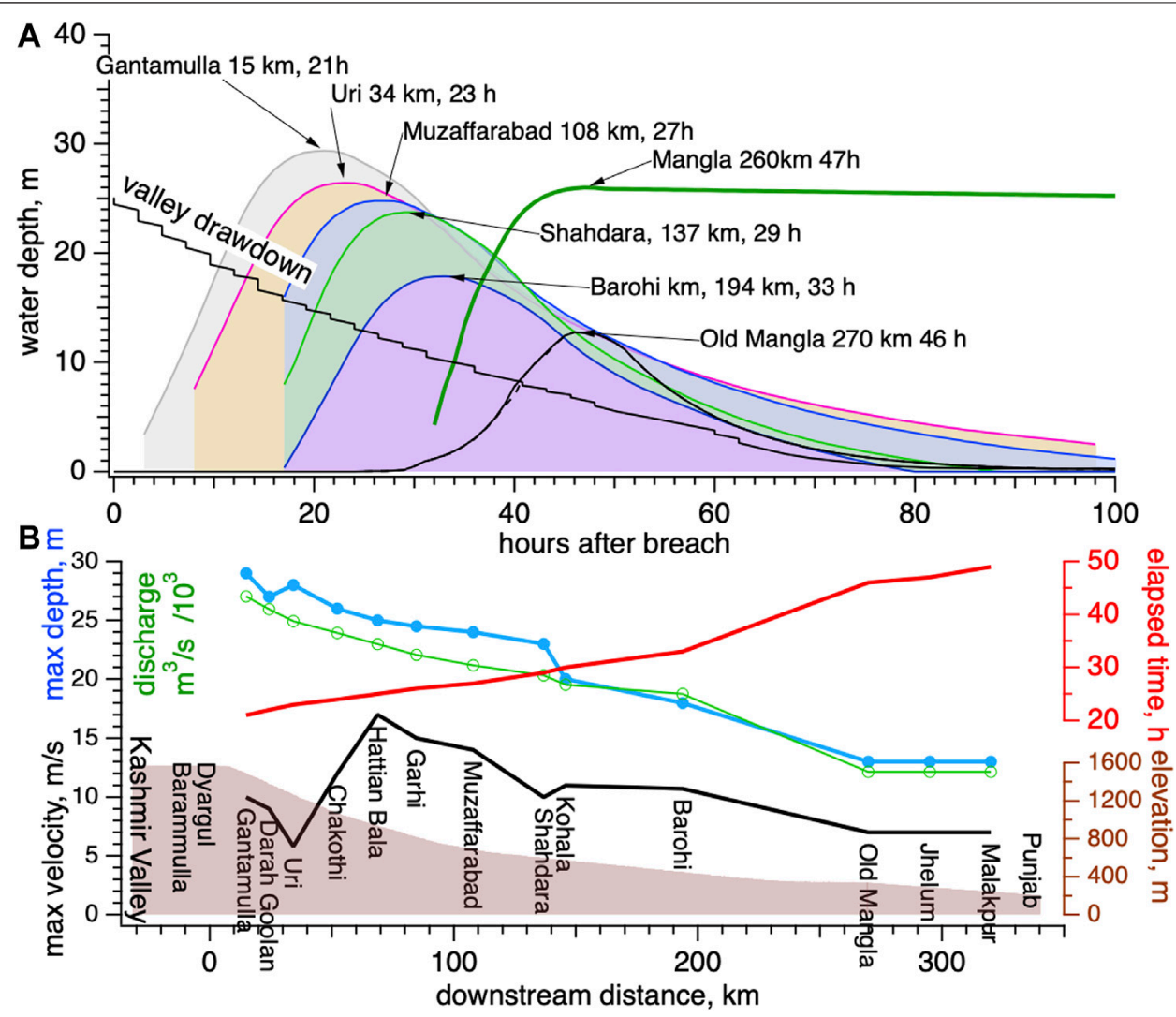

FIGURE 4 | (A) Calculated Kashmir Valley drainage history (solid blue line) and downstream flood surge levels for breach of a $25 \mathrm{~m}$ high dam near Dyargul (Figure 3) using a hybrid Manning's coefficient for a forested Jhelum overbank. Values in parenthesis at select locations indicate the delay in surge maximum between a smooth and a forested channel. A synthetic filling curve for a hypothetically empty Mangla Reservoir reaches its spillway level after 2 days (dashed blue line). (B). River profile (brown shading), and maximum stream velocity (black line) at indicated locations for forested overbank model. Dashed black line indicates velocities without forested overbank, which we consider unlikely in Medieval times. Peak local flood depth (blue), peak discharge (green), and elapsed time from breach to maximum surge (red) on the Jhelum are also shown downstream from Dyargul. The phase velocity of the peak flood surge increases downstream from 6 to $17 \mathrm{~km} / \mathrm{h}$.

velocities were rapid (5-17 m/s) the peak surge height far from the breach developed slowly, rising at less than $1 \mathrm{~m} / \mathrm{h}$, which would have permitted people and animals downstream to escape to higher ground. Flood heights peaked after 1 day near Uri, and after 2 days at the ancient, now submerged, village of Mangla.

As expected the larger channel friction imposed on our forested overbank models slowed maximum velocities (by $30 \%$ ) and reduced surge heights downstream (by 7\%) (Table 1A) with delays of up to $9 \mathrm{~h}$, compared to models with a smooth channel. In addition to the $25 \mathrm{~m}$ high dam at Dyargul, we calculated the downstream surge from a dam with a $70 \mathrm{~m}$ spillway at Dyargul releasing an $88 \mathrm{~km}^{3}$ lake, corresponding to the $1,640 \mathrm{~m}$ dominant shoreline level in Figure 2A. Maximum velocities associated with this model attained $14 \mathrm{~m} / \mathrm{s}$, with an average surge height of $62 \mathrm{~m}$.

To estimate the sensitivity of the model results to the downstream position of the landslide, we investigated the effect on peak parameters (Table 1A) for a flood released from a taller dam but identical impounded water level. To achieve this we examined the flood resulting from breach of an hypothetical $98 \mathrm{~m}$-high dam near Gantamulla (at $34.14^{\circ} \mathrm{N}, 74.19^{\circ} \mathrm{E}$ ). As expected this resulted in considerably increased maximum downstream velocities $\left(V_{\text {ave }} 18 \mathrm{~m} / \mathrm{s}\right.$, $V_{\max } 21 \mathrm{~m} / \mathrm{s}$ for a smooth channel, and $V_{\text {ave }} 17 \mathrm{~m} / \mathrm{s}$ and $V_{\max } 19 \mathrm{~m} / \mathrm{s}$ for a forested overbank). Surge heights for this model averaged $74 \mathrm{~m}$.

Finally, we examined two extreme models for the breach of dams at Gantamulla with heights of $173 \mathrm{~m}$ and $273 \mathrm{~m}$, that would impound lakes with $100 \mathrm{~m}$ and $200 \mathrm{~m}$ depths in the Kashmir Valley bracketing shorelines mapped by De Terra and Paterson (1939) (Figures 1, 2). The forested overbank models for these models yielded maximum velocities of $21 \mathrm{~m} / \mathrm{s}$ and $31 \mathrm{~m} / \mathrm{s}$, and average surge depths of $170 \mathrm{~m}$ and $350 \mathrm{~m}$ respectively (Table $\mathbf{1 B}$ ).

\section{MOBILIZATION OF BOULDERS IN THE BED OF THE JHELUM}

Indirect confirmation for our maximum flow velocities takes the form of massive boulders (diameters $3 \mathrm{~m}-25 \mathrm{~m}$ ) strewn in 
TABLE 1A | Smooth channel results (using uniform Manning's coefficient of 0.05)

\begin{tabular}{|c|c|c|c|c|c|c|c|c|c|c|c|c|c|c|c|c|}
\hline \multirow{3}{*}{ Location } & \multirow{3}{*}{ lat } & \multirow{3}{*}{ long } & \multirow{3}{*}{ elevation m } & \multirow[b]{3}{*}{ km } & \multicolumn{3}{|c|}{25 m landslide dam } & \multicolumn{3}{|c|}{$98 \mathrm{~m}$ landslide dam } & \multicolumn{3}{|c|}{173 m landslide dam } & \multicolumn{3}{|c|}{273 m landslide dam } \\
\hline & & & & & $\mathbf{H}_{\max }$ & $\mathbf{V}_{\max }$ & $D_{\max }$ & $\mathbf{H}_{\max }$ & $\mathbf{V}_{\max }$ & $D_{\max }$ & $\mathbf{H}_{\max }$ & $\mathbf{V}_{\max }$ & $D_{\max }$ & $\mathbf{H}_{\max }$ & $\mathbf{V}_{\max }$ & $D_{\max }$ \\
\hline & & & & & $\mathbf{m}$ & $\mathrm{m} / \mathrm{s}$ & $\mathrm{m}^{3} / \mathrm{s}$ & $\mathbf{m}$ & $\mathrm{m} / \mathrm{s}$ & $\mathrm{m}^{3} / \mathrm{s}$ & $\mathbf{m}$ & $\mathrm{m} / \mathrm{s}$ & $\mathrm{m}^{3} / \mathrm{s}$ & $\mathbf{m}$ & $\mathbf{m} / \mathbf{s}$ & $\mathrm{m}^{3} / \mathrm{s}$ \\
\hline Baramulla & 34.209 & 74.339 & 1574.5 & -6.0 & & & & & & & & & & & & \\
\hline Dyargul & 34.186 & 74.306 & 1570.2 & 0.0 & 29.5 & 11 & 28,151 & & & & & & & & & \\
\hline Guntamulla & 34.143 & 74.188 & 1496.8 & 14.9 & 29 & 10 & 27,029 & 95 & 20 & 175,823 & 98 & 21 & 180,000 & 196 & 32 & 360,000 \\
\hline Darah & 34.129 & 74.109 & 1379.9 & 24.3 & 27 & 9 & 25,953 & 90 & 18 & 157,834 & 95 & 19 & 160,036 & 192 & 30 & 320,072 \\
\hline Uri & 34.086 & 74.047 & 1269.8 & 34.2 & 28 & 5.8 & 24,919 & 85 & 15 & 131,392 & 92 & 17 & 142,286 & 189 & 36 & 284,573 \\
\hline Chakothi & 34.118 & 73.88 & 1072.8 & 52.2 & 26 & 12 & 23,926 & 80 & 18 & 112,345 & 85 & 20 & 126,505 & 178 & 31 & 253,011 \\
\hline Hattian Bala & 34.17 & 73.745 & 944.2 & 68.8 & 25 & 17 & 22,973 & 77 & 20 & 109,384 & 83 & 23 & 112,475 & 175 & 32 & 224,949 \\
\hline Garhi & 34.227 & 73.617 & 821.8 & 84.7 & 24.5 & 15 & 22,057 & 74 & 20 & 100,000 & 81 & 22 & 110,000 & 172 & 31 & 210,000 \\
\hline Muzaffarabad & 34.355 & 73.469 & 691.0 & 107.9 & 24 & 14 & 21,179 & 73 & 21 & 98,699 & 80 & 21 & 108,373 & 170 & 30 & 200,000 \\
\hline Shahdara & 34.157 & 73.493 & 606.7 & 136.8 & 23 & 10 & 20,335 & 73 & 21 & 98,699 & 78 & 22 & 104,420 & 172 & 33 & 174,110 \\
\hline Kohala & 34.085 & 73.5 & 574.7 & 145.8 & 20 & 11 & 19,525 & 70 & 20 & 95,929 & 75 & 23 & 100,612 & 171 & 32 & 151,572 \\
\hline Barohi & 33.711 & 73.601 & 452.0 & 193.7 & 18 & 10.7 & 18,747 & 68 & 18 & 94,165 & 73 & 21 & 96,942 & 173 & 31 & 131,951 \\
\hline Old Mangla & 33.148 & 73.753 & 300.0 & 269.8 & 13 & 7 & 12,149 & 93 & 10 & 93,407 & 68 & 20 & 80,000 & 163 & 25 & 80,000 \\
\hline \multicolumn{5}{|c|}{ Kashmir Valley Reservoir volume, cubic km } & \multicolumn{3}{|c|}{$14.5 \pm 2.5 \mathrm{~km}^{3}$} & \multicolumn{3}{|c|}{$14.5 \pm 2.5 \mathrm{~km}^{3}$} & \multicolumn{3}{|c|}{$\approx 177 \mathrm{~km}^{3}$} & \multicolumn{3}{|c|}{$\approx 460 \mathrm{~km}^{3}$} \\
\hline \multicolumn{5}{|c|}{ Kashmir Valley lake level (m), Fill time (y) } & \multicolumn{3}{|c|}{$1,595 \mathrm{~m}, \approx 3$ years } & \multicolumn{3}{|c|}{$1,595 \mathrm{~m}, \approx 3$ years } & \multicolumn{3}{|c|}{$1,670 \mathrm{~m}, \approx 40$ years } & \multicolumn{3}{|c|}{$1,770 \mathrm{~m}, \approx 85$ years } \\
\hline \multicolumn{5}{|c|}{ Dam height $(\mathrm{m})$, time to drain valley (days) } & \multicolumn{3}{|c|}{25 m, 4 days } & \multicolumn{3}{|c|}{98 m, 4 days } & \multicolumn{3}{|c|}{173 m, 17 days } & \multicolumn{3}{|c|}{273 m, 27 days } \\
\hline \multirow{2}{*}{\multicolumn{5}{|c|}{ Kashmir Lake flood depth }} & \multicolumn{3}{|c|}{$25 \mathrm{~m}$} & \multicolumn{3}{|c|}{$25 \mathrm{~m}$} & \multicolumn{3}{|c|}{$100 \mathrm{~m}$} & \multicolumn{3}{|c|}{$200 \mathrm{~m}$} \\
\hline & & & & & & 1,497 & & & 1,470 & & & 1,470 & & & 1,470 & \\
\hline
\end{tabular}

Maximum downstream surge depths (Hmax), velocities (Vmax) and discharge (Dmax) for the 25-m-high landslide dam breached by Suyya at base elevation 1,497 m, compared to hypothetical $98 \mathrm{~m}, 173 \mathrm{~m}$ and $273 \mathrm{~m}$ high landslide dams at Gantamulla (at base elevation =1,470 m). These dams impound lake levels at 1595 m, 1,670 m and 1,770 m, corresponding to lake depths of $25 \mathrm{~m}, 100 \mathrm{~m}$ and $200 \mathrm{~m}$ respectively in the Kashmir Valley. Distances in column five are derived from the interpolated downstream channel at $10 \mathrm{~m}$ intervals.

TABLE 1B I Synthetic flood surge results for 50 m wide central channel (with Manning's coefficient 0.05), flanked by forested hillsides (assigned Manning's coefficient of 0.16$)$.

\begin{tabular}{|c|c|c|c|c|c|c|c|c|c|c|c|c|c|c|c|}
\hline \multirow{3}{*}{ Location } & \multicolumn{3}{|c|}{25 m Dyargul dam } & \multicolumn{3}{|c|}{70 m Dyargul dam } & \multicolumn{3}{|c|}{98 m Gantamulla dam } & \multicolumn{3}{|c|}{173 m Gantamulla dam } & \multicolumn{3}{|c|}{273 m Gantamulla dam } \\
\hline & $\mathbf{H}_{\max }$ & $\mathbf{V}_{\max }$ & $\underline{D_{\max }}$ & $\mathbf{H}_{\max }$ & $\underline{\mathbf{V}_{\max }}$ & $D_{\max }$ & $\mathbf{H}_{\max }$ & $\underline{\mathbf{V}_{\max }}$ & $\underline{D_{\max }}$ & $\mathbf{H}_{\max }$ & $\underline{\mathbf{V}_{\max }}$ & $\underline{D_{\max }}$ & $\mathbf{H}_{\max }$ & $\underline{\mathbf{V}_{\max }}$ & $D_{\max }$ \\
\hline & $\mathbf{m}$ & $\mathrm{m} / \mathrm{s}$ & $\mathrm{m}^{3} / \mathrm{s}$ & $\mathbf{m}$ & $\mathrm{m} / \mathrm{s}$ & $\mathrm{m}^{3} / \mathrm{s}$ & $\mathbf{m}$ & $\mathrm{m} / \mathrm{s}$ & $\mathrm{m}^{3} / \mathrm{s}$ & $\mathbf{m}$ & $\mathrm{m} / \mathrm{s}$ & $\mathrm{m}^{3} / \mathrm{s}$ & $\mathbf{m}$ & $\mathbf{m} / \mathbf{s}$ & $\mathrm{m}^{3} / \mathrm{s}$ \\
\hline \multicolumn{16}{|l|}{ Baramulla } \\
\hline \multicolumn{16}{|l|}{ Dyargul } \\
\hline Guntamulla & 26 & 7 & 29 & 69 & 10 & 31 & 92 & 18 & 92 & 96 & 19 & 170 & 189 & 30 & 350 \\
\hline Darah & 25 & 6 & 29 & 67 & 9 & 30 & 87 & 16 & 87 & 92 & 17 & 150 & 186 & 28 & 310 \\
\hline Uri & 25 & 4.5 & 27 & 65 & 7.5 & 30 & 82 & 13 & 82 & 89 & 15 & 131 & 183 & 31 & 275 \\
\hline Chakothi & 25 & 12 & 26 & 66 & 14 & 29 & 77 & 16 & 77 & 81 & 18 & 117 & 172 & 29 & 243 \\
\hline Hattian Bala & 23 & 10 & 25 & 64 & 12 & 28 & 73 & 18 & 73 & 80 & 21 & 102 & 169 & 30 & 215 \\
\hline Garhi & 23 & 9.5 & 24 & 63 & 11.5 & 27 & 71 & 18 & 71 & 78 & 20 & 100 & 166 & 29 & 200 \\
\hline Muzaffarabad & 23 & 6 & 23 & 62 & 8 & 25 & 70 & 17 & 70 & 77 & 19 & 98 & 164 & 28 & 190 \\
\hline Shahdara & 21 & 5.5 & 22 & 61 & 7.5 & 25 & 70 & 19 & 70 & 75 & 21 & 94 & 166 & 31 & 164 \\
\hline Kohala & 20 & 6.5 & 21 & 60 & 8.5 & 23 & 67 & 18 & 67 & 72 & 20 & 91 & 165 & 30 & 142 \\
\hline Barohi & 17 & 7 & 20 & 56 & 9 & 23 & 64 & 16 & 64 & 70 & 19 & 87 & 167 & 29 & 122 \\
\hline Old Mangla & 13 & 6 & 20 & 50 & 7 & 16 & 63 & 15 & 63 & 63 & 18 & 70 & 157 & 23 & 71 \\
\hline
\end{tabular}

Locations and units as in Table 1A, except for discharge, which here is listed in units of $1,000 \mathrm{~m}^{3} / \mathrm{s}$ truncated to the nearest $1,000 \mathrm{~m}^{3} / \mathrm{s}$. The $70 \mathrm{~m}$ Dyargul model emulates an hypothetical catastrophic breach of a Dyargul landslide with a 1,640 m spillway level, and an $88 \mathrm{~km}^{3}$ Lake Kerewa volume.

the Jhelum stream bed. The bed transport of river boulders is approximately proportional to the stream velocity. An empirical relationship derived by Costa (1983) for the translation of boulders with diameter, $d$, (where $d$ is in $\mathrm{mm}$ ) is quantified in Eq. 1.

$$
\text { Velocity }=0.18 d^{0.487} \mathrm{~m} / \mathrm{s}
$$

The equation implies that the maximum dimensions of a river-bed boulder can be used to indicate the maximum velocity of that segment of the stream since the boulder was last mobilized. This, of course, does not provide the maximum velocity ever experienced in the stream, however, a measure of this maximum is available for these largest flood surges from the dimensions of boulders where the Jhelum debouches into the Punjab plains, or in the case of drainage of ancient Kerewa lakes, on the eastern Potwar Plateau.

We quantified the major and minor dimensions of 126 river boulders $>3 \mathrm{~m}$ diameter in the bed of the Jhelum visible between Baramulla and Mangla on Google Earth imagery (Supplementary Material 4). Shadow lengths permit an approximate estimate of their vertical dimensions, but these 


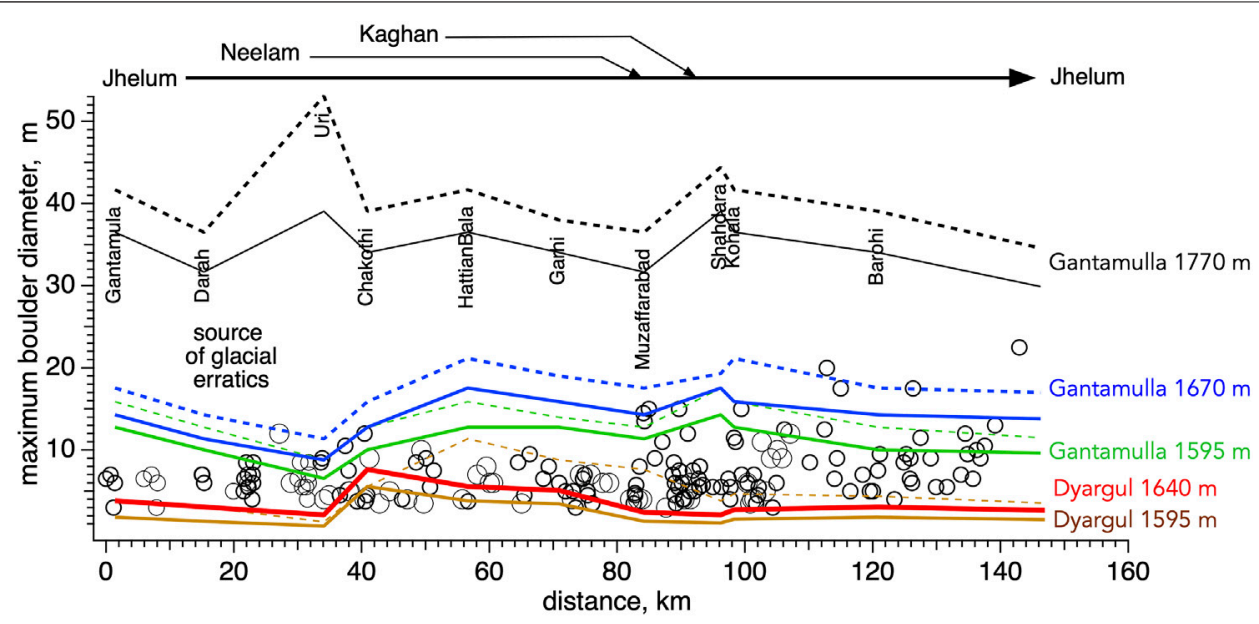

FIGURE 5 | Confluences along the Jhelum River and observed mean boulder diameters (circles, from Supplementary Material 4). The lines represent the synthetic boulder-mobilization curves derived from calculated downstream velocities (Table 1B) from different locations and spillway levels using Eq. 1. Solid lines are calculated assuming forested valley sides, dashed lines from a smooth channel. The lowest of the curves represents the boulder mobility threshholds calculated for Suyya's $25 \mathrm{~m}$ breach at Dyargul.

were not recorded due to their uncertain depths of burial, and variable river depths. Hostilities in Kashmir have prevented ground inspection of these boulders to ascertain their petrology or provenance, or to estimate their date of deposition (c.f. Huber et al., 2020). Godwin-Austen, 1859 documents massive granite boulders mantling the $60 \mathrm{~m}$ high-river terraces at Gujar Bandi $\left(34.25^{\circ} \mathrm{N}, 73.85^{\circ} \mathrm{E}\right)$, and the narrow river terrace between Gingal Fort $\left(34.135^{\circ} \mathrm{N}, 74.113^{\circ} \mathrm{E}\right)$ and Uri (a combined downstream distance of $26 \mathrm{~km}$ ) that were derived from the Kaj Naj porphyry in the mountains $15 \mathrm{~km} \mathrm{NE}$ of Gingal. An equidimensional boulder near the Buniyar temple with linear dimensions exceeding $6 \mathrm{~m}$ is described by Verchère (1866 p.99), who provides a petrological summary of its distinctive $\leq 12 \mathrm{~cm}$-long twinned albite crystals. Wadia, 1941 mentions glacial erratics near here the "size of small cottages".

Although the average diameter of prominent Jhelum boulders is $7.5 \pm 3.5 \mathrm{~m}$, two populations may be distinguished (Figure 5): those upstream from Muzaffarabad average $6.2 \pm 2.0 \mathrm{~m}$ with a maximum diameter of $15 \mathrm{~m}$, whereas those below the confluence with the Neelam at Muzaffarabad average $8.4 \pm 4.0 \mathrm{~m}$ with maximum dimension of $25 \mathrm{~m}$. This may arise because boulders below Muzaffarabad include those rolled down the Neelum and Khagan rivers. For example, a prominent gneiss in the bed below Kohala may have been transported from a source $\approx 70 \mathrm{~km}$ north by glacial outburst floods along the Khagan River (A. Khan, personal communication 2021; Supplementary Material 4). We note that the largest mapped boulders in the lower reaches of the narrow gorge between Muzaffarabad and the Mangla reservoir consist of angular, sub-rectangular slabs that may have spalled locally from formations flanking the valley. No massive boulders are found downstream below the Mangla reservoir where the Jhelum debouches into the Punjab or in the gravel terraces flanking the river (Mugnier, personal communication 2021), nor have they been reported from the Punjab, or the palaeo-course of the Jhelum in the eastern Potwar plateau (Theobald, 1880; Cotter 1929; De Terra and Paterson, 1939). In contrast, boulders measuring more than $10 \mathrm{~m}$ are found on the Potwar plateau flanking the lower course of the Indus, which Cotter (1929) ascribes to paleo-outburst floods from the Indus River.

To facilitate comparisons between observed boulder dimensions and synthetic velocities we convert the velocities in Table 1B to the theoretical boulder dimension they are capable of mobilizing, using Eq. 1 (Figure 5). If we consider the mean size of boulders only above Muzaffarabad $(6.2 \mathrm{~m})$ their transport would require river velocities of $\approx 12.6 \mathrm{~m} / \mathrm{s}$ close to the maximum $12 \mathrm{~m} / \mathrm{s}$ velocity we calculate above Uri for our preferred $25 \mathrm{~m}$-high dam at Dyargul (Table 1B). If we confine our comparison to the Dyargul/Muzaffarabad segment before the confluence with the Neelam river, just $30 \%$ of the large boulders would be mobilized by the forested Dyargul breach, compared to $70 \%$ for the smooth channel model, and $40 \%$ for a $70 \mathrm{~m}$-high forested breach. In contrast, breaches of the three different levels of dam we consider at Gantamulla would have mobilized most, or all of the boulders. The highest of these extreme floods would have mobilized boulders with diameters upwards of $25 \mathrm{~m}$, dumping them in the Punjab Plains near the debouchment of the Jhelum near the town of that name. No such large boulders have been reported.

Our preferred forested-overbank model for the Dyargul $25 \mathrm{~m}$ high landslide breach results in velocities that are too slow to "clean out" the current distribution of boulders above Muzaffarabad. A 70-m-deep Lake Kerewa level released from Dyargul, would be able to mobilize some of these boulders, but its $>60 \mathrm{~m}$ surge level would probably have damaged extant Buddhist temples downstream. This 

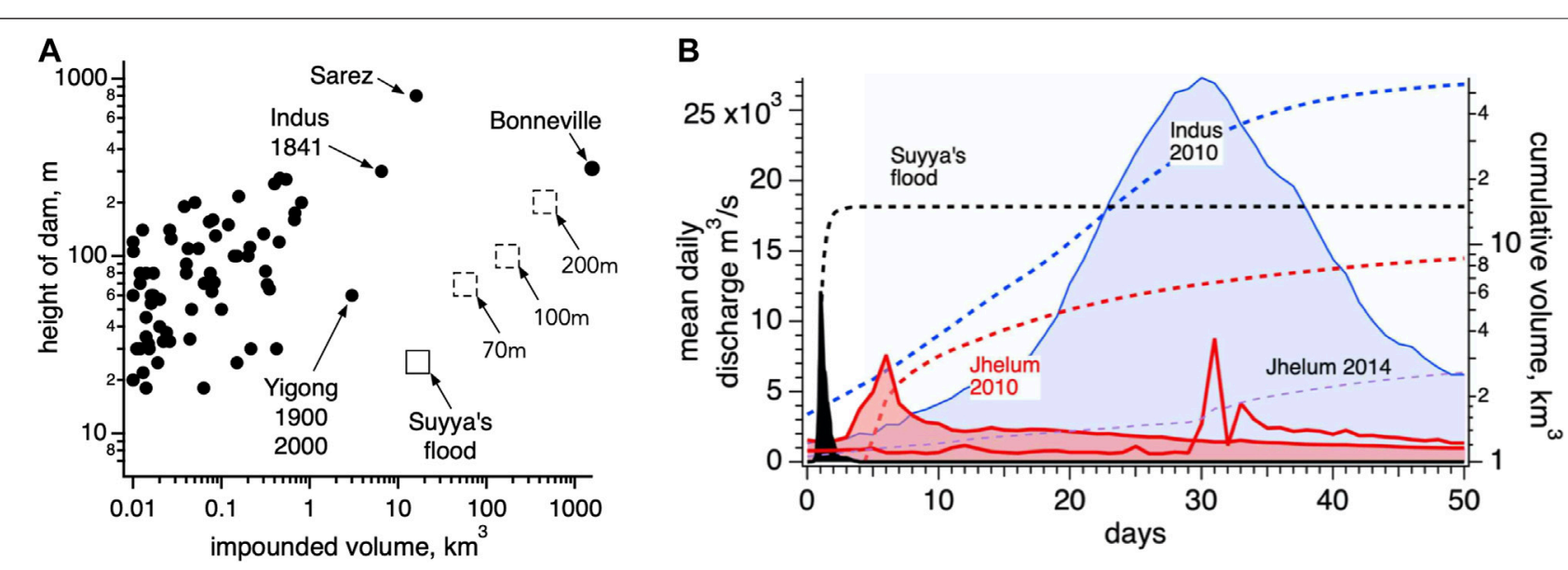

FIGURE 6 | Comparisons between Suyya's Medieval flood and other extreme flood events. (A) Dam height vs impounded volume from Costa and Schuster (1991), Delaney and Evans (2011), Guo et al (2020), Hewitt, (2011), Malde (1968). Dashed squares (with numerical Kashmir Valley flood depths) indicate hypothetical Kashmir outburst floods we have evaluated in the present article. (B) Discharge (shaded) and cumulative volume (dashed) computed at Mangla released by Suyya's flood (black 4 days spike), compared with values observed on the Jhelum hydrograph north of the Mangla Dam (red shading) during recent extreme precipitation floods, and a hydrograph on the Indus at Kotri during the 2010 August-September Pakistan floods (blue shading). An arbitrary start time is used for each flood. The cumulative volume vs time curves (dashed lines integrate the daily discharge) are referenced to the logarithmic right hand scale.

suggests that the abandoned $1,640 \mathrm{~m}$ shoreline was unlikely to have been associated with the ninth century breach.

\section{DISCUSSION}

We calculate that the impounded waters that had taken three or more years to accumulate, drained from the Kashmir Valley in less than 4 days following Suyya's breach of the landslide near Dyargul. Flood levels near Bij Behara would have receded on the first day, and $>10 \mathrm{~m}$ flood levels at Srinagar would have receded by the second day. The rapid drainage of the Kashmir lake is consistent with the Rajatarangini's description of stranded wriggling fish in the dark mud resembling a night sky of "black darkness and stars" (Stein 1898, 5:94).

The slow rise in downstream surge height (Figure 4A) resembles that described for the 1858 Indus flood (Shaw, 1871) and is in marked contrast to the 1841 downstream outburst surge on the Indus that arrived as an "overwhelming irresistible wall of discolored waters" (Falconer, 1841; Mason, 1929; Delaney and Evans, 2011). Our calculations, however, ignore the possible transition from fluid flow to debris flow, which can occur on gradients steeper than 1\% (Cui et al., 2010).

Historical evidence for the passage of the downstream flood is absent. The Rajatarangini relates events surrounding the death of Avantivarman's successor at Peliasa (ancient Bolyasaka, 34.177N, 73.7829E (Stein, 1899a, 5:225) with no mention of flood damage, but this river terrace village, like the medieval temples at Buniyar $\left(34.144^{\circ} \mathrm{N}, 74.189^{\circ} \mathrm{E}\right)$, and Detha Mandir $\left(34.128^{\circ} \mathrm{N}, 74.078^{\circ} \mathrm{E}\right)$ may have been spared due to their elevation on terraces $\approx 31 \mathrm{~m}$ and $\approx 21 \mathrm{~m}$ above the river channel. The survival of Holocene river terraces at downstream levels above $40 \mathrm{~m}$, but their absence between $40 \mathrm{~m}$ and recent $\approx 8 \mathrm{~m}$ terraces [De Terra and Paterson (1939)], provides additional weak support that channel scour during Suyya's flood did not exceed $25 \mathrm{~m}$. This observation would appear to refute the possibility that a lake with a 1,640 m level lake was released by Suyya in the ninth century, because this significantly larger surge would have been associated with an average $>60 \mathrm{~m}$ high surge.

Catastrophic breaches of lakes impounded much above the $1,640 \mathrm{~m}$ contour appear to be unnecessary to explain the observed distribution of Jhelum boulders. The Punjab Plains where the Jhelum currently debouches are devoid of large boulders, although we admit that they may have been buried by subsequent finer deposits. The caveat to this conclusion is that the survival of boulders $>20 \mathrm{~m}$ depends on the existence of suitably competent, and large, source rocks to withstand the violence of their downstream passage without fragmentation.

We consider it probable that the multiple shorelines recorded in the Kashmir Valley by De Terra and Paterson (1939) constitute a record of more than one Quaternary flood/drainage event. The steep bare slopes rising $>2 \mathrm{~km}$ above the flanks of the Jhelum reveal several active scars that may have been former landslide source regions. Korup \& Montgomery (2008) and Guo et al. (2020) note that an abundant supply of sediments and the frequent impounding of Himalayan rivers by landslides near the edge of the Tibetan Plateau may have been responsible for arresting or retarding their headward erosion. They envision a process whereby a periodic flux of sediments effectively retards bedrock incision. The inflection point in the Jhelum river profile we identify in Figures 1, 3 is close to the mapped location of the Main Central Thrust (Seeber and Gornitz, 1983), but also coincides with the region of high relief fueling landslides downstream from 
Baramulla, which appears to provide an independent example of this process. The corollary of this equivalence is that landslides in this stretch of the river may be more frequent than implied by the single example of which we know in the past millennium. Small landslides blocked the road in the Jhelum gorge after the 1885 earthquake (Englishman, 1885) for example, but there were no reports of river blockages. The repeated occurrence of landslide blockages of the river provides additional support for the legendary emergence of the Kashmir valley from a lake in Kashmir's early histories being based on one or more of these flooding events. The prominent 1,640 m shoreline in Figures 2A, $40 \mathrm{~m}$ deeper than Suyya's flood, is a potential candidate for this legendary flood.

\section{Comparison With Recent Floods}

In Figure 6 we compare the depth/volume of the ninth century Kashmir flood with a global compilation of extreme landslide dammed lakes. We show the largest events complied by Costa \& Schuster (1991), supplemented with data from other extreme floods such as the Late Pleistocene Lake Bonneville drainage event (Malde, 1968), the 1900 and 2000 Yigong outburst floods (Guo et al., 2020) and the 1913 formation of Lake Sarez, currently stable, but whose potential breach has been modeled by Alford and Schuster (2000). The potential flood volumes of two hypothetical $100 \mathrm{~m}$ and $200 \mathrm{~m}$ deep lakes we consider above, exceed known historical outburst floods in the Himalaya, and approach that associated with the Bonneville flood. If the absence of mega-boulders in the Punjab is used as a measure of maximum outburst flood velocity, these ancient Kashmir lakes may have drained without catastrophic failures.

Although landslides in the Jhelum gorge constitute a future hazard, given various engineering strategies that are now available, it is improbable that a future deep flood would be permitted to develop in the Kashmir Valley. For example, a $200 \mathrm{~m}$ thick landslide blocking the current channel for a distance of $5 \mathrm{~km}$ is considered possible. Such a landslide would be too large to breach by overtopping or channeling, but a bed-rock bypass tunnel could no doubt be constructed to drain the maximum Jhelum discharge in a time short compared to the rise time of flood waters in the Kashmir Valley. As an aside, we note that the $1 \mathrm{~km}$-long, $4 \mathrm{~m}$-diameter, railway tunnel on the SW end of the Kashmir Valley currently provides an unintended spillway for floods in the valley should they exceed the $1760 \mathrm{~m}$ contour level (Bukhari and DarYousuf, 2015). However, it is doubtful that the scale of potential landslides, and impounded floods in the Jhelum gorge have been considered in hazard planning in the region. Three major hydroelectric dams now impede the path of Jhelum outburst flood: Uri, Kohala and Mangla, but their combined capacity would be insufficient to absorb the volume of water released by a repeat of Suyya's Medieval flood. We envisage that even were such a flood to occur at the present time, the overflow spillways of their various reservoirs would probably be protected from dangerous debris flows by their reservoirs acting as stilling ponds.
To place Suyya's megaflood in the context of recent floods, we compared our synthetic discharge vs time history at Old Mangla (before it was flooded by the Mangla reservoir) with the time history of the 2010 flood on the Jhelum and Indus (FFC, Federal Flood Commission, 2014), the largest in recent time (Figure 6B). Suyya's 4 days surge released approximately twice the volume that the 2010 flood in the Jhelum released in the months of August and September 2010, but only 1/3 of the volume of flood waters on the main Indus channel near Sukkur. The discharge near Dyargul for the hours following the Medieval breach exceeded $29,000 \mathrm{~m}^{3} / \mathrm{s}$. This discharge was equivalent to half the present-day annual mean discharge summed for all the rivers of the Indian subcontinent (Kumar et al., 2005).

\section{CONCLUSIONS}

Numerical models of the Medieval flood whose engineered release from the Kashmir Valley is ascribed to Suyya in the ninth century yielded maximum downstream velocities of $12 \mathrm{~m} / \mathrm{s}$ consistent with the transport of loose boulders with diameters $<6 \mathrm{~m}$. Few boulders $>7 \mathrm{~m}$ in diameter were mapped above Muzaffarabad, but many are found below Muzaffarabad where we calculate velocities to have slowed, but where ambiguity arises due their possible source regions in the upper reaches of the Kaghan and Neelam rivers. Our synthetic models indicate that the downstream rise of the flood surge may have occurred sufficiently slowly for villagers to escape to higher ground. Our preferred models for the Medieval flood include a low Manning's coefficient to emulate a $50 \mathrm{~m}$-wide smooth lower channel, with a larger Manning's coefficient appropriate for forested overbanks and terraces. More complex models incorporating debris in the flow were considered unwarranted due to poor historical constraints on the location, and geometry of the slide.

Although we are reasonably certain of the Dyargul (Figure 2, west of Sheeri) location of the $25 \mathrm{~m}$-high landslide responsible for the ninth-century flood, and have possibly identified a landslide breccia near the abandoned Yaksadara channel, the precise details of its geometry and source region remain speculative. Our calculation of breach incision and widening rates indicates that the a $25 \mathrm{~m}$-high landslide dam occupying the full $590 \mathrm{~m}$ rockchannel width at Dyargul would probably have been reamed out by the flood in less than a day, removing evidence of the presence of the landslide. We also explored the catastrophic failure of dams at Gantamulla, $15 \mathrm{~km}$ downstream from Dyargul, impounding lakes in the Kashmir Valley (Table 1B) with $25 \mathrm{~m}, 100 \mathrm{~m}$ and $200 \mathrm{~m}$ depths (corresponding to $21 \mathrm{~km}^{3}, 277$ and $460 \mathrm{~km}^{3}$ lake volumes respectively). These extreme lake volumes are consistent with lake shorelines in the Kashmir Valley, but prior to our study it was not known whether they were drained causing catastrophic downstream floods. Calculated downstream flow velocities for catastrophic release of these waters averaged 2.3, 2.6 and 4 times faster than the Dyargul location, with accordingly greater carrying power 
(boulders up to $25 \mathrm{~m}$ in diameter). The absence of any massive boulders where the Jhelum currently debouches into the plains of the Punjab, or in the easternmost Potwar Plateau, suggests that these former great lakes did not drain catastrophically.

The numerous ancient shorelines in the Kashmir valley permit an interpretation that landslide blockage in the Jhelum gorge was not limited to a single filling/drainage event. The implications of a prominent peak in ancient shorelines near the $1,640 \mathrm{~m}$ contour (flooding parts of the capital, Srinagar, to $>40 \mathrm{~m}$ depth) deserves future investigation.

Regular blockage of the Jhelum gorge by landslides in the $20 \mathrm{~km}$ downstream from Baramulla is further suggested by the current proximity of headward erosion in the Jhelum to the region of $>3 \mathrm{~km}$ relief in the Jhelum gorge where hillslopes adjoining the Jhelum are steep and unstable. In the eastern Himalaya, headward erosion of the Brahmaputra appears to have been slowed by a regularly renewed mantle of sediments that retard bedrock incision. The Medieval Kashmir landslide lies close to the Jhelum erosional knickpoint and may be the locus of a similar process.

The volume of water released by Suyya's 4 days flood exceeded the volume of the 2010 monsoon-induced, month-long flood on the Jhelum by a factor of two. Were a similar flood to be released today, an empty Mangla reservoir would overtop its spillways after 2 days releasing a further $5 \mathrm{~km}^{3}$ to the Punjab plains. Modern engineering methods exist that would no doubt be enlisted to breach any future large-scale landslide on the Jhelum to inhibit severe flooding of the Kashmir valley, or a subsequent uncontrolled downstream flood of the sort we describe in this article.

A historical and geological evaluation of extreme events provides a broader perspective on flood and landslide hazards in the NW Himalaya than can be gleaned from the study of river discharge data from the past few centuries (c.f. Ashraf et al., 2002; Bhat et al., 2017). The Kashmir Valley is currently exposed to frequent flood hazards, but these are limited in depth by the level of the outlet at Baramulla. Despite their adverse societal impact, these present-day floods have been many tens of meters shallower than those impounded by landslides in the Jhelum in the past several thousands of

\section{REFERENCES}

Agrawal D. P., Dodia R., Kotlia B. S., Razdan H., and Sahni A. (1989). The Plio-Pleistocene Geologic and Climatic Record of the Kashmir valley, India: A Review and New Data. Palaeogeogr. Palaeoclimatol. Palaeoecol. 73, 267-286. doi:10.1016/00310182(89)90008-4

Alford D., and Schuster R. (2000). Usoi Landslide Dam and Lake Sarez. (New York: U.N. Publication ISDR Prevention Series 1E.00.III.M), 1, 101. ISBN 92-1-132022-4

Ashraf A., Naz R., and Roohi R. (2012). Glacial lake Outburst Flood Hazards in Hindukush, Karakoram and Himalayan Ranges of Pakistan: Implications and Risk Analysis. Geomatics, Nat. Hazards Risk 3 (2), 113-132. doi:10.1080/19475705.2011.615344 years. A challenge for future study will be to date Kashmir's ancient shorelines to learn how often landslides and major impoundment events may have occurred in the valley.

\section{DATA AVAILABILITY STATEMENT}

The original contributions presented in the study are included in the article/Supplementary Material, further inquiries can be directed to the corresponding author.

\section{AUTHOR CONTRIBUTIONS}

All authors listed have made a substantial, direct, and intellectual contribution to the work and approved it for publication.

\section{CONFLICT OF INTEREST}

The authors declare that the research was conducted in the absence of any commercial or financial relationships that could be construed as a potential conflict of interest.

\section{ACKNOWLEDGMENTS}

We thank Dan Jantzen for early Indian maps, J-L Mugnier for information on boulder dimensions near Mangla, and Robert S. Anderson, Asif Khan, and Mike Searle for insightful discussions. Critical reviews from Simon Cook and two reviewers significantly improved the manuscript. Maham Tariq Alvi and Rohit Budhwani provided guidance on the use of the numerical flood surge model. RB was supported by National Science Foundation award EAR2028557.

\section{SUPPLEMENTARY MATERIAL}

The Supplementary Material for this article can be found online at: https://www.escubed.org/articles/10.3389/esss.2021. 10040/full\#supplementary-material

Basavaiah N., Appel E., Lakshmi B. V., Deenadayalan K., Satyanarayana K. V. V., Misra S., et al. (2010). Revised Magnetostratigraphy and Characteristics of the Fluviolacustrine Sedimentation of the Kashmir basin, India, during Pliocene-Pleistocene. J. Geophys. Res. 115, B08105. doi:10.1029/2009JB006858

Bhat M. S., Ahmad B. A, Alam A., Farooq H., and Ahmad S. (2019). Flood hazard Assessment of the Kashmir Valley Using Historical Hydrology. J. Flood Risk Manage. 12, 1-13. doi:10.1111/jfr3.12521

Bhatt D. K. (1989). Lithostratigraphy of Kerewa Group, Kashmir Valley, India and a Critical Review of its Fossil Record. Mem. Geol. Surv. India 122, 1-85.

Bilham R., and Bali B. S. (2013). A Ninth century Earthquake-Induced Landslide and Flood in the Kashmir Valley, and Earthquake Damage to Kashmir's Medieval Temples. Bull. Earthquake Eng. 12, 79-109. doi:10.1007/s10518-013-9504-x 
Bilham R. (2019). "Himalayan Earthquakes: a Review of Historical Seismicity and Early 21st century Slip Potential," in Himalayan Tectonics: A Modern Synthesis. Editors P. J. Treloar and M. P. Searle (London: Geological Society, London, Special Publications), 483, 423-482. 5 February 2019. doi:10.1144/ SP483.16

Brunner G. W. (1995). "HEC-RAS River Analysis System,". Version 1.0 in Hydraulic Reference Manual (Hydrologic Engineering Center Davis CA).

Brunner G. W., Sanchez D. A., Molls D. T., and Parr D. D. A. (2018). HEC-RAS Verification and Validation Tests. Davis, California: US Army Corps of Engineers Institute for Water Resources Hydrologic Engineering Center (CEIWR-HEC).

Bukhari K., and DarYousuf A. M. M. (2015). Tunnel Construction in Pir Panjal (Himalaya) Using NATM, (Case Study T-74r Railway Tunnel of Katra-Banihal Section of Kashmir Rail Project, I-Manager's. J. Civil Eng. 6 (1), 47-52. No. 12016.

Burbank D. W., and Johnson G. D. (1982). Intermontane-basin Development in the Past $4 \mathrm{Myr}$ in the north-west Himalaya. Nature 298, 432-436. doi:10.1038/298432a0

Burbank D. W., and Johnson G. D. (1983). The Late Cenozoic Chronologic and Stratigraphic Development of the Kashmir Intermontane basin, Northwestern Himalaya. Palaeogeogr. Palaeoclimatol. Palaeoecol. 43 (1983), 205-235. doi:10.1016/ 0031-0182(83)90012-3

Burrard S. G. (1913). Baramulla and Anantnag Districts, 63. Calcutta: Survey of India, 360. Map $43 \mathrm{~J} / 111$.

Burrard S. G. (1912)., 43 J/8 163. Calcutta: Survey of India, 360.Kashmir north (Baramulla) and Muzaffarabad DistrictsMap.

Costa J. E. (1983). Paleohydraulic Reconstruction of Flash-Flood Peaks from boulder Deposits in the Colorado Front Range. Geol. Soc. America Bull. 94 (8), 986-1004. doi:10.1130/0016-7606(1983) $94<986$ :profpf $>2.0 . c 0 ; 2$

Costa J. E., and Schuster R. L. (1991), Documented Historical Landslide Dams from Around the World USGS Open File Report, 91-239 pp. 494, 1991 Available at: http://pubs.er.usgs.gov/publication/ ofr91239 Doi10.3133/ofr91239

Cotter G. de. P. (1929). The Erratics of the Punjab. Rec. Geol. Surv. India 41, 327-336.

Cui P., Dang C., Cheng Z., and Scott K. M. (2010). Debris Flows Resulting from Glacial-Lake Outburst Floods in Tibet, China. Phys. Geogr. 31 (6), 508-527. doi:10.2747/0272-3646.31.6.508

De Terra H., and Paterson T. T. (1939). Studies on the Ice Age in India and Associated Human Cultures, 493. Washington: Carnegie Inst, 354.

Delaney K. B., and Evans S. G. (2011). "Rockslide Dams in the Northwest Himalayas (Pakistan, India) and the Adjacent Pamir Mountains," in Central Asia Ch 7 in Natural and Artificial Rockslide Dams. Editors S. G. Evans, R. L. Hermanns, A. Strom, and G. Scarascia-Mugnozza (Afghanistan,TadjikistanSpringer).

Englishman The. (1885). Another Shock on the 19th June at 3:50 Pm and the Road Near Baramulla Is Quite Impassable in Consequence of the Earthquake. The Englishman Newspaper 4, 23, 1885 . June 1885.

Falconer H. (1841). Letter to the Secretary of the Asiatic Society, on the Recent Cataclysm of the Indus. J. Asiatic Soc. Bengal 10, 615-620.

Farr T. G., Rosen P. A., Caro E., Crippen R., Duren R., Hensley S., et al. (2007). The Shuttle Radar Topography Mission. Rev. Geophys. 45, RG2004. doi:10.1029/2005RG000183

FFC, Federal Flood Commission (2014). "Ministry of Water and Power," in Annual Flood Report 2014 (Islamabad: Government of Pakistan), 81.

Froehlich David. C. (2008). Embankment Dam Breach Parameters and Their Uncertainties. ASCE. J. Hydraulic Eng. 134 (No. 12), 1708-1721. December 2008ISSN 0733-9429. doi:10.1061/(asce) 0733-9429(2008)134:12(1708)

Godwin-Austen H. H. (1859). On the Lacustrine or Karewah Deposits of Kashmere. Q. J. Geol. Soc. 15, 221-229. doi:10.1144/ gsl.jgs.1859.015.01-02.47
Guo C., Montgomery D. R., Zhang Y., Zhong N., Fan C., Wu R., et al. (2020). Evidence for Repeated Failure of the Giant Yigong Landslide on the Edge of the Tibetan Plateau. Sci. Rep. 10 (1), 14371. doi:10.1038/s41598-020-71335-w

Hassan G. (1896). Tarikh-i-Hassan Compiled by Pir Ghulam Hassan (Hassan Shah), Kashmir Series of Texts and Studies, 82, 2 Volumes. Srinagar: Research and Publication Department, Jammu and Kashmir Government. reprint in Persian script.

Hewitt K. (2011). "Rock Avalanche Dams on the Trans Himalayan Upper Indus Streams: A Survey of Late Quaternary Events and hazard-related Characteristics 177-205 in Natural And Artificial Rockslide Dams," in Alexander Strom, Gabriele Scarascia-Mugnozza. Editors Stephen G. Evans and Reginald L. Hermanns (Springer).

Huber M. L., Lupker M., Gallen S. F., Christl M., and Gajurel A. P. (2020). Timing of Exotic, Far-Traveled boulder Emplacement and PaleoOutburst Flooding in the central Himalayas. Earth Surf. Dynam. 8 (3), 769-787. doi:10.5194/esurf-8-769-2020

lyengar R. N., Sharma D., and Siddiqui J. M. (1999). Earthquake History of India in Medieval Times. Indian J. Hist. Sci. 34 (3), 181-237.

Korup O., and Montgomery D. R. (2008). Tibetan Plateau River Incision Inhibited by Glacial Stabilization of the Tsangpo Gorge. Nature 455, 786-789. doi:10.1038/nature07322

Kramer M., and Holmes J. (2009). Taxonomy and Palaeoecology of Ostracoda from the Middle to Late Pleistocene Upper Karewa Formation of Kashmir Valley, Northern India, J. Micropalaeontol.. 28 (1): 25-36. doi:10.1144/jm.28.1.25

Kumar R., Singh R. D., and Sharma K. D. (2005). Water Resources of India. Curr. Sci. 89 (5), 794-811.

Lone A. M., Achyuthan H., Shah R. A., Sangode S. J., Kumar P., Chopra S., et al. (2020). Paleoenvironmental Shifts Spanning the Last 6000 Years and Recent Anthropogenic Controls Inferred from a High-Altitude Temperate lake: Anchar Lake, NW Himalaya. The Holocene 30 (1), 23-36. doi:10.1177/0959683619865599

Malde H. E. (1968). The Catastrophic Late Pleistocene Bonneville Flood in the Snake River plain, Idaho. U.S. Geol. Surv. Prof. paper 596, 52. doi:10.3133/pp596

Mason K. (1929). Indus Floods and Shyok Glaciers. Himalayan J. 1, 10-29.

Montgomerie T. G . (1859). 1/4' to the Mile Map of Kashmir, Scale 4 miles to the Inch. Dehra Dun: Survey of India.

Rockwell T. K., Meltzner A. J., and Haaker E. C. (2018). Dates of the Two Most Recent Surface Ruptures on the Southernmost San Andreas Fault Recalculated by Precise Dating of Lake Cahuilla Dry Periods. Bull. Seism. Soc. Amer. 108, 2634-2649. doi:10.1785/0120170392

Seeber L., and Gornitz V. (1983). River Profiles along the Himalayan Arc as Indicators of Active Tectonics. Tectonophysics 92, 335-367. doi:10.1016/0040-1951(83)90201-9

Shah R. A., Achyuthan H., Lone A. M., Kumar S., Kumar P., Sharma R., et al. (2020). Holocene Palaeoenvironmental Records from the HighAltitude Wular Lake, Western Himalayas. The Holocene 30 (5), 733-743. doi:10.1177/0959683619895592

Shaw R. (1871). High Tartary, Yarkand, and Kashgar. 1st ed.. London: John Murray, 486.

Stein A. (1897). Notes on Maps of Ancient Kasmir and Srinagar: Impr. Paris: Nat, $75-85$

Stein A. (1899a). Ancient Geography of Kashmir, 68. Calcutta: J. As. Soc Bengal. Part 1, 1-231, and Extra No. 2 (3 maps).

Stein M. A. (1898). Kalahana's Rajatarangini:a Chronicle of the Kings of Kashmir, Translated by M. Aurel Stein, 1. CalcuttaDelhi: Constable and Coreprint Motilal Banarsidass Publishers, 402.

Stein A. (1899b). Ancient Geography of Kashmir. Reprinted without Maps in Kalhana's Rajatarangini: A Chronicle of the Kings of Kashmir, 2. Delhi 2009: Motilal Banarsidass Publishers, 347-494. 555.

Theobald W. (1880). On Some Pleistocene Deposits of the Northern Punjab, and the Evidence They Afford of an Extreme Climate during a Portion of that Period. Rec. Geol. Surv. India 13, 221-241. 
Verchère A. H. (1866). Kashmir, the Western Himalaya and the Afghan Mountains. J. .Asiatic Soc. Bengal 33 (2), 89-133.

Vörösmarty C. J., Fekete B., and Tucker B. A. (1998). "River Discharge Database,". Version 1.1 in Available through the Institute for the Study of Earth, Oceans, and Space (Durham NH (USA): University of New Hampshire). RivDIS v1.0 supplement.

Wadia D. N. (1919). Geology of India. London: Macmillan, 398.

Wadia D. N. (1941). Pleistocene Ice-Age Deposits of Kashmir. Proc. Natl. Inst. Sci. India 7, 49-59.

Wadia D. N. (1934). The Cambrian-Trias Sequence of North-Western Kashmir (Parts of Muzaffarabad and Baramulla Districts). Rec. Geol. Surv. India 68, 121-176.

Walker J., C Johnstone H., Montgomerie T. G., Robinson D. G., Barron W., Sandeman J. E., et al. (1867). "Parts of Districts Hazara and Rawalpindi (Punjab) and of Native State, Kashmir," in With Revisions to $1886.1 / 4^{\prime \prime}: 1$ mile Dehra Dun.

Waugh A. S. (1859). Map of Kashmir 1/2":1 Mile. Surveyed 1855-57. Dehra Dun: Survey of India.
Zhong Q., Wang L., Chen S., Chen Z., Shan Y., Zhang Q., et al. (2021). Breaches of Embankment and Landslide Dams - State of the Art Review. Earth-Science Rev. 216, 103597-108252. ISSN. doi:10.1016/j.earscirev.2021.103597

Publisher's Note: All claims expressed in this article are solely those of the authors and do not necessarily represent those of their affiliated organizations, or those of the publisher, the editors and the reviewers. Any product that may be evaluated in this article, or claim that may be made by its manufacturer, is not guaranteed or endorsed by the publisher.

Copyright (C) 2021 Urooj, Bilham, Bali and Ahmed. This is an open-access article distributed under the terms of the Creative Commons Attribution License (CC BY). The use, distribution or reproduction in other forums is permitted, provided the original author(s) and the copyright owner(s) are credited and that the original publication in this journal is cited, in accordance with accepted academic practice. No use, distribution or reproduction is permitted which does not comply with these terms. 